\title{
Managing Plight and Measuring Contribution of Female Workers in Tea Industry of Bangladesh
}

\author{
Mohammad Lutfar Rahman ${ }^{1 *}$, Harwindar Singh ${ }^{2}$, and Khairir Khalil ${ }^{3}$ \\ ${ }^{1}$ International University of Business Agriculture and Technology (IUBAT), Dhaka, Bangladesh; \\ ${ }^{2,3}$ School of Business, Malaysia University of Science and Technology, Malaysia. \\ Corresponding Author*
}

\begin{abstract}
Bangladesh Tea Industry dates back 1856 when British companies established this agrobased industry in hilly area of Sylhet and Chittagong districts. To clean jungle, to make nurseries and to nurture the nurseries at a certain level, then transferring the tea plants from nurseries to plantation which constitutes continuous whole the year-round work, they need regimented work force who would work in the tea plantation for generations, they migrated workers from famine prone areas of India alluring them to enjoy a better life earning wages working in tea estates. The migrated workers succumbed their allurement and last 170 years they are still working generations to generation in tea estates with meagre wages but their life style has not been developed. A cup of tea when served looks pleasant but who knows there are endless plights endured by workers to make a cup of tea with soothing liquor right from tea plantation job, picking quality leaves and to make tea. Their fate is not changed to start a better living but the owners earn huge margin from selling quality tea to international markets.
\end{abstract}

Key words: Agro based, migrated, liquor, wages, international tea market

\section{INTRODUCTION}

$\mathrm{T}$ ea is a labor-oriented enterprise as it is agro-based. It requires labor at every stage of its work right from clearance of various fields, making nurseries, planting tea, nurturing, picking leaf and lastly manufacturing tea in the factory. (The et al. 2011).

Tea plantations in Greater India including Bangladesh is a legacy of the British colonial administration. The colonial government in Assam, north-eastern India, started the first tea plantation on an experimental basis in the 1830s and within two decades private entrepreneurs had developed and expanded tea plantations in north-eastern India as well as in other parts of colonial India (Sharma and Das, 2009: 16; Singh et al., 2006: 2). In the initial period of plantations, workers were recruited from different backward tribal areas, many of which were afflicted by famine (Behal and Mohapatra, 1992; Singh et al., 2006: 14). The objective of such a form of worker recruitment was to 'retain a captive labor force at low wages' without developing a free labor market (Chakrabarti and Sarkar, 2005: 3; Siddique, 1995: 91 2). Family rather than single settlement was encouraged not only to prevent male workers from becoming recalcitrant or absconding but also to assure the reproduction of a labor force (Chatterjee, 2001: 80-2). Females were also preferred as workers because of their sensitive fingertips suitable for tea plucking and lower inclination to unionize (Sharma and Das, 2009: 69- 70).

The total labor requirements of a tea estate are made up of the labor required for field operations and factory operations. In addition, labor is required for service activities such as transport. $99 \%$ of the field operations are labor oriented. The productivity of these field activities are influenced by the level of yield, the wage rate, terrain and experience of the activity.(Kodithuwakku \& Priyanath, 2010)

Labor distribution in Bangladesh tea industry is based on 1:1 (labor: acreage) ratio.

Total area under tea cultivation $=59609.43$

Hectare $=147235.29$ acre

Total permanent labor deployed for 147235.29 acre $=100843$ workers

Total casual workers deployed $=21997$ workers

Total workers (permanent and casual) in tea industry of Bangladesh $=122840$

Now, let us make a study of a working women's contribution in tea productivity and in return what the company provides her.

Total yearly tea production on average in Bangladesh: 85 million kilograms

Green leaf required 340 million kilograms (4:1 Green leaf and made tea ratio)

On an average a tea picker harvests $17 \mathrm{~kg}$ green leaf per day from end March to December 31 in 200 days in a year after deducting weekly holiday, national holiday, sick leave, annual leave etc.

A green leaf picker harvests total green leaf in a year $=4913$ $\mathrm{kg}$ green leaf just to complete her task. But during peak season she plucks more green leaf at a piece rate above task which sometimes gets double. We can easily conclude that a woman worker (Green leaf picker) plucks 4913 × $2=9826 \mathrm{~kg}$ green leaf on an average in harvesting time.

Daily wages of a female worker are Tk 100 and for picking 
extra leaf they earn Tk 20 which makes Total daily earning of a female worker Tk 120

Total number of tea pickers required to harvest green leaf (340 million $\mathrm{kg}$ ) to make 85 billion $\mathrm{kg}$ tea, 34602 pickers annually.

Cost of per kg green leaf throughout the year Tk 2.44, will go further if quantum of green leaf plucking is further high

Other expenses like fuel, machinery etc.$=\mathrm{Tk} 850$ million

Total expenditure to make 85-million-kilogram tea $=\mathrm{Tk} 6000$ million approximately (which includes green leaf price, male worker wages, fuel, machinery maintenance, staff salary, Managers salary, bungalow maintenance etc.)

Manufacturing cost of per kilogram made tea $\mathrm{Tk} 70$, costing goes down if production goes high

Total earning from sale proceeds of 85 -million-kilogram tea $=$ Tk 20,000 million

Owners of Bangladesh tea Industry make yearly profit $=\mathrm{Tk}$ 14000 million from 85-million-kilogram tea production and sale.

\section{LITERATURE REVIEW}

There remains always deficit of workers especially female workers in picking tea leaf during peak season which lasts from May to October every year apart from the abovementioned fact of having a total 122840 workers available which is much below from requisite 147235 workers based on standard labor: acreage (1:1) ratio. Recruitment of temporary laborers for few months available from redundant workers in tea estates can meet up the deficit to some extent. But availability of female workers $100 \%$ in peak season is really difficult to carry out harvesting crop and hence deployment of male workers in picking leaf has become indispensable compromising the quality of green leaf.

Every tea tribe's woman apart from her household chores use to go to tea garden to work such as plucking tea leaves, nursing or any other works related to tea production for generating income. So, in the absence of the mother, the girl child takes the responsibility of the family from household work to taking care of younger sibling setting aside her study and attending schools. As result she loses interest in study and performs poor in the examination which ultimately results in dropping out. (Kr Gogoi Assistant Professor, Handique Librarian, and Kendriya Mahavidyalaya 2014). As soon as she drops out from school she is enrolled as temporary worker in tea garden to pick green leaf. Sometimes she may be lucky to have been permanently enrolled as permanent worker to fill in the vacant position of her father, mother or any blood related relative goes retirement or dies of old age.

Tea industry cannot compromise with the quality and quantity of tea production by deploying less requisite number of tea pickers in the field. Once it is done entire chain of command for quality harvest is broken down. On the other hand, frequency of harvest will be shortened to the great fall of production and as a result green leaf in the bush becomes coarse which ultimately will make poor quality of made tea.

Entire tea industry has 122840 (permanent 100843 and casual 21997) workers to work in tea plantation in Bangladesh. Amongst the number of workers about $60 \%$ workers are deployed in plucking and $40 \%$ are deployed in other works in the garden in normal period. In peak season about $90 \%$ workers are deployed in plucking for some days. Hence other works are getting hampered. In order to continue other seasonal works gardens recruit people from redundant workers available in the garden keeping first priority to picking green leaf preferably with women workers then if need be male workers are deployed in picking green leaf on urgent basis.

Bangladesh is the ninth largest tea producing country and few years ago ranked the tenth largest tea exporting country in the world. At present tea export from Bangladesh has come to almost nil for increase in home tea consumption although production increased significantly. Tea production has increased from $900 \mathrm{~kg}$ per hectare yield in nineties in last century to $1500 \mathrm{~kg}$ per hectare yield currently in present century. This gigantic success has been possible due to threedimensional development works in Bangladesh tea industry viz: massive infilling, block infilling and replacement replanting.

\section{Research Data and Constructs}

This article is based on data collected earlier for a different study (Lutfar Rahman 2016) in which the researchers examined the relationship between female workers toiling hard in quality tea leaf picking in plantation job and user vis a vis company satisfaction.

\section{RESEARCH METHODOLOGY}

The researcher first consulted secondary literature to find out what had been written on annual reports of Bangladesh Tea Association which is the platform of tea industry owners union. Information was also directly gathered from female workers in tea estates who used to work in tea gardens in picking green leaf which is considered bread and butter for the workers as well as for the owners. Trade union people of workers side were interviewed in depth about their perceptions of hard work in tea gardens, standard of their living and wages they get through agreement between workers union and owners union. Participants taking part in this prestudy were presented with open-ended questions, which allowed them to express their opinions fully.

\section{RESULTS}

Replacements of old tea plants with new varieties could bring about considerable gains. Huque (2007) showed that mature and young bushes are more productive than old bushes and it would be advantageous if farmers were to continuously replace the old bushes. Huque observed that with adoption of 
young tea bushes production can be increased by $3,818 \mathrm{~kg} /$ hectare all other things held constant.(Kagira, Kimani, and Githii 2012). Bangladesh Tea Industry adopted the principle of uprooting old tea phase wise and in that place new tea has been planted after the land has been properly developed. Productivity of old tea declines after it attains 40 years of age. Bangladesh tea industry will have to go a long way to complete the gigantic task as the days are going by the age of tea plants are increasing and tea bushes are getting old at an increasing rate and their yield starts decreasing. So, the above-mentioned three-dimensional activities will continue and there is possibility to increase the yield further from 1500 $\mathrm{kg}$ per hectare to $2500 \mathrm{~kg}$ per hectare within next 10 years provided the development activities continue at this rate. As density of plant population per hectare will increase so the density of leaf in each tea bush will increase. In this way requirement of tea pickers preferably women will increase many folds in near future. If the authority fails to keep sufficient contingencies of female workers, tea industry will have to witness major catastrophe of low quality and low quantity of tea production.

The area around Sylhet is a traditional tea growing area. In the tea garden area, most of the land is hill slopes and tea garden worker and their family live in hilly place. They have not their own land for building their houses. So, they live in small and soil made houses. Tea garden refers to a place where disadvantage indigenous people live with poverty, poor health and nutrition, densely, inadequate lighting, lack of safe drinking water, water logging during rains, absence of toilet facilities and non-availability of basic physical and social services. Particularly older people suffer more in tea garden areas.(Pal and Hussain 2016)

The following two hypotheses concerning attitudes on productivity and costs are tested: first, that worker attitudes have no effect on the cost of production; second, that the effects of worker attitude are factor neutral, having no effect on the relative efficiencies of capital, production-worker labor, nonproduction labor, and materials.("Worker Attitudes and the Cost of Production," n.d.)

Attitude is a combination of evaluation, feeling and action. Worker may have attitude of disliking the assigned job to accomplish, may feel the assigned work is not suitable for him and may make an attempt to switchover to another work. In each case he will not be successful to do according to his evaluation, feeing and action. He will have to succumb to the instruction of the management to accomplish company's goals and objectives. The womenfolk of the tea industry after doing the cores of household work goes to the plantation at 8 am in the morning for tipping green leaf and stay there till $5 \mathrm{pm}$ in the afternoon. On return home they are again becomes busy for preparing supper and for next day work. So, they have got no choice on leading their day to day life. By day time they are fully under the control of the garden management and after working hour they are fully under the control of their husbands. What they earn as weekly wages are drawn by their husbands from the office maximum portion of which are spent after consumption of wines by the husband. As they spend money after liquor on priority basis their actual food intake for nutrition is insufficient. On the other hand, womenfolk work in the garden mainly in picking green leaf whole day, the most tedious job in tea industry and men workers are engaged in the works other than picking green leaf in most cases except one or two cases when they are engaged in picking green leaf under compulsion of the management just to control the quality of green leaf vis a vis quality of tea.

The tea workers are one of the lowest paid groups, they relied on the mercy and goodwill of the managers as they could be evicted anytime and under any trivial pretext. The lack of land tenure and ownership constrained the freedom and movement of the laborers and was thus the invisible shackles that bound them to the plantation (Chhetri, 2013:124).("Identities," n.d.).Planters gave workers plots of land to cultivate paddy and vegetables and allowed them to get involved in a variety of other activities, including 'rearing and grazing cattle, raising poultry, collecting forest produce, wood cutting [and] fishing ... within the garden grant and in its periphery' (Gupta, 1992: 184-5). Although planters feared that allotting garden plots to workers would keep them away from tea garden work, this means of patronage functioned 'as a new instrument for control' (Gupta, 1992: 184). Those allotted garden plots were bonded to the estate (Siddique, 1995: 107).

\section{DISCUSSION}

It is very true when we see that women workers even after lot of persecution do not leave husband's house as well as the garden. They toil in the garden from morning to evening picking green leaf which is bread and butter for the workers as well as to the company since productivity of the garden depends upon the quantum of green leaf plucked by a woman worker and also productivity is the amount of production yielded per acre of the garden. So, women workers play a pivotal role in the garden unlike male workers who work maximum cases in jobs other than plucking green leaf except one or two cases on emergency basis to control the plucking round in order to maintain quality of tea production. But in exchange of their hard work what they are paid by their employers. It is just equal pay to their male counterpart who stay in the field almost half of the total time spent by the women workers in the field.

Tea tribes are conceptually illiterate people. They hardly think of changing their life style by adopting the occupation of the urban-industrial societies which need modern education. Noneducation, poverty, addiction of males to country beer, poor standard of living, poor health facility etc. are the common problems in their lives.(Kr Gogoi Assistant Professor, Handique Librarian, and Kendriya Mahavidyalaya 2014). In spite of the above facts tea tribes especially the women workers do not leave the garden work and stay in the garden with multiple of drawbacks of living conditions like noneducation, poverty, male partner's addiction to liquor, poor 
living standard, poor health facility like poor Medicare services, poor sanitation etc. The workers often get snake and mosquito bite. Cough, cold and fever are common diseases among the workers. They spray insecticide and pesticide with bare hands without using protective gloves, masks, spectacles and soap. Hazards of working while standing for a long in the sun and rain cause chronic leg ache. They also lack safe drinking water at work place.("Life_in_the_Labour_Lines_Situation_of_Te," n.d.). Due to unhygienic sanitary conditions and inadequate water supply facilities many waterborne and excreta related diseases such as diarrhea, amoebic dysentery, bacillary dysentery, typhoid, cholera, salmonellosis, shigellosis, dengue, yellow fever, jaundice, schistosomiasis, filariasis, plague, leptospirosis etc. are commonly occurred in all study areas. It may be noted that children are more sensitive to the diseases.(Mushtaq Ahmed et al. 2006). The women tea workers adopted survival strategies centered on food, health \& hygiene and financial solvency. They struggle a lot to manage food items for their family members. Women tea workers try to involve in different extra income source since salary from garden is not enough to maintain livelihood but isolation from mainstream society is a great hindrance here. For health purpose they mostly depend on indigenous and traditional survival strategies.(Islam, Rana, and Rashid 2015).

\section{RECOMMENDATION}

The government should make a separate body to look after tea workers and make some stringent laws to protect these workers to get exploited. Government should make labor unions who will look upon the rights of the plantation workers, government should connect plantation workers to the labor law departments directly so that workers can directly go there and fight for their right, owners of the plantation field should strictly tell to have proper working hours and should give proper wages especially to women workers. Safety of them(Panwar 2017) women and children should be prioritized and have proper facilities for them (Panwar 2017)

Moreover, these workers as being human should have all kind of human rights whereas they are mostly discriminated in our society. From the above discussion, it is concluded that tea garden workers are still lagging behind in terms of socially, economically and culturally. The most responsible reason that comes forward from my study is illiteracy because literate people are always aware of the irrights(Ahmad et al. 2015).

\section{BIBLIOGRAPHY}

[1] Ahmad, I, M Yasin, A Rowshon, and Rafikul Islam A K M. 2015. "Study on Socio-Economic and Educational Condition of Tea Worker at Sylhet in Bangladesh" 5 (5): 1-8. https://doi.org/10.5376/jtsr.2015.05.0005.

[2] Ahmed, Mesbahuddin. 2010. "Trade Union Movement in Bangladesh: Issues , Agenda and Legislation," 1-15. http://jatiyosramikjote.org/tubook.pdf.

[3] Ahmed, Mushtaq, M A Hoque, M S K A Sarkar, M A I Chowdhury, and A Begum. 2006. "Socio-Cultural Evaluation of Sanitation Hygiene in Sylhet City of Bangladesh." Asian Research Publishing Network 1 (3): 68-78.

[4] Alam, Khan Tariqul, and Sayeed Ahmed College. n.d. "Organizational Knowledge Creation in Agricultural Reform: A Case Study in Iijima Town, Japan" 11: 41-63.

[5] Armstrong, Kathy, David Bailey, Alex De Ruyter, Michelle Mahdon, and Holli Thomas. 2008. "Auto Plant Closures, Policy Responses and Labour Market Outcomes: A Comparison of MG Rover in the UK and Mitsubishi in Australia." Policy Studies 29 (3): 343-55. https://doi.org/10.1080/01442870802160051.

[6] Aspromourgos, T. 2012. "The Machine in Adam Smith's Economic and Wider Thought." Journal of the History of Economic Thought $34 \quad$ (4): 475-90. https://doi.org/10.1017/S105383721200048X

[7] Ataur, Mohammed, and Sowmen Rahman. 2015. "Natural and Traditional Defense Mechanisms to Reduce Climate Risks in Coastal Zones of Bangladesh" 7: 84-95.

[8] Banerjee, Supurna, and Phd Sociology. 2014. "Nurturing Resistance: Agency and Activism of Women Tea Plantation Workers in a Gendered Space."

[9] Bayraktar-Sağlam, Bahar, and Hakan Yetkiner. 2014. "A Romerian Contribution to the Empirics of Economic Growth." Journal of Policy Modeling 36 (2): 257-72. https://doi.org/10.1016/j.jpolmod.2014.01.001.

[10] Beale, N, and S Nethercott. 1987. "[The Health of Industrial Employees Four Years after Compulsory Redundancy]." The Journal of the Royal College of General Practitioners 37 (302): 390-94.

[11] Bhowmik, Sharit K, and Kanchan Sarker. 2002. "Worker Cooperative as Alternative Production Systems: A Study in KolKata, India." Work and Occupations 29 (4): 460-82. https://doi.org/10.1177/073088802237559. 